Dapat diakses pada: http://jkb.ub.ac.id/index.php/jkb/article/view/1325

Jurnal Kedokteran Brawijaya Vol. 29, No. 2, Agustus 2016, pp. 170-174

Online Publish First: 29 Agustus 2016

Laporan Kasus

Article History: Received 1 Oktober 2015, Accepted 15 Maret 2016

\title{
Recurrent Aggressive Angiomyxoma
}

\section{Angiomiksoma Agresif Rekurens}

\author{
Imam Rasjidi $\mathrm{M}^{1}$, Christine Susanto ${ }^{2}$, Ryan Putra Wondany ${ }^{2}$ \\ ${ }^{1}$ MRCCC Siloam Hospitals Semanggi \\ ${ }^{2}$ Faculty of Medicine Pelita Harapan University
}

\begin{abstract}
Aggressive angiomyxoma (AA), a rare mesenchymal tumor with high recurrence rate and infiltrative nature, most generally arises in the vulvovaginal region, perineum, and pelvis of women in reproductive age peaking from age 31 to 35 but uncommonly found on men. It appears as a slow-growing gelatinous mass, which commonly asymptomatic. Imaging studies including USG, CT scan, and MR imaging are of great importance for the diagnosis of AA on identifying the mass characteristics. This paper reports a case of a 37 year old P3AO woman with a lump on the left side of vaginal lip for 2 weeks before admission. The lump was soft to touch and was not painful, without other accompanying symptoms. Past medical history showed the lump has recurred after being surgically removed. On physical examination, a lump was found on the left vulva with soft consistency. CT scan showed a well-circumscribed hypodense mass on left labia majora and showed post contrast wall enhancement. Fine needle aspiration biopsy was done and showed hypocellular smear with myxoid matrix and bleeding. The mass was then removed by vulvectomy procedure. Histopathological analysis of the mass shows infiltration of myxoid stroma with blood vessels consistent with aggressive angiomyxoma. In conclusion, AA is usually asymptomatic and has high tendency of recurrence. Imaging procedure is useful on identifying mass characteristics and biopsy can be done to establish AA diagnosis. Surgery is the main modality for the treatment of AA, and administration of gonadotropin-releasing hormone analogue can prevent further recurrence.
\end{abstract}

Keywords: Aggressive angiomyxoma, gonadotropin-releasing hormone agonist, recurrent

\begin{abstract}
ABSTRAK
Angiomiksoma agresif (AA) merupakan tumor mesenkimal langka yang sering muncul di area vulvovagina, perineum, dan pelvis wanita, lebih jarang ditemui di pria, dengan angka rekurensi yang tinggi dan kecenderungan infiltrasi jaringan sekitarnya. Sering ditemukan pada usia reproduktif dengan puncak pada usia 31 hingga 35 tahun. Tumor ini terlihat sebagai masa lunak yang bertumbuh secara perlahan. Pemeriksaan radiologis memegang peran penting dalam penegakan diagnosis, seperti USG, CT scan, dan MRI, dalam mengidentifikasi karakteristik massa. Artikel ini melaporkan kasus wanita P3A0 berusia 37 tahun dengan benjolan pada bibir vagina kiri dengan konsistensi lunak sejak 2 minggu sebelum masuk rumah sakit. Benjolan tersebut bersifat lunak dan tidak nyeri tanpa ada gejala lainnya. Riwayat penyakit dahulu menunjukkan adanya rekurensi setelah dilakukan pembedahan. Dari pemeriksaan fisik didapatkan benjolan di vulva kiri dengan konsistensi lunak. CT scan menunjukkan massa hipodense berbatas tegas pada labia mayora kiri dan scan dengan kontras menunjukkan penebalan dinding. Biopsi jarum halus menunjukkan apusan hiposelular dengan matriks miksoid dan pendarahan. Massa tersebut kemudian diangkat menggunakan prosedur vulvektomi. Analisa histopatologis dari massa menunjukkan infiltrasi stroma miksoid dengan pembuluh darah sesuai dengan angiomiksoma agresif. Pasien juga diberikan injeksi Leuprorelin setelah pembedahan. Sebagai kesimpulan, AA biasanya bersifat asimptomatik dan memiliki kecenderungan berulang. Pemeriksaan radiologis berperan penting dalam mengidentifikasi karakteristik massa. Pemeriksaan biopsi jarum halus dapat menegakkan diagnosis AA. Pembedahan merupakan modalitas utama tatalaksana penyakit ini, dan pemberian analog gonadotropin releasing hormone dapat mencegah rekurensi penyakit ini.
\end{abstract}

Kata Kunci: Angiomiksoma agresif, gonadotropin-releasing hormone agonists, rekuren

Korespondensi: Imam Rasjidi M. MRCCC Siloam Hospitals Semanggi, Garnisun Dalam, No. 2-3, Street, Semanggi Tel. (021) 29962888 Email:imam_rasjidi@yahoo.co.id 


\section{INTRODUCTION}

Aggressive angiomyxoma is a rare tumor of vulvovaginal and perineal region. Although the tendency to infiltrate adjacent organs emphasize its aggressiveness, it is classified as benign tumor since it has no metastasize capability (1). The incidence of this disease peaks on the third decade of life and most commonly occurred on female $(2,3)$. This disease has very high recurrence rate after being surgically removed (4) and is accompanied with scarce symptoms occurrence (4), thus every patient with recurrent painless nodule in perineal and vulvovaginal region has to pay more attention towards this disease.

In this paper, we report a case of aggressive angiomyxoma with multiple prior recurrences with history of complicated surgery by a general surgeon, and resolved by gynecologist oncologist's surgical intervention. This case represents a most typical appearance of aggressive angiomyxoma considering its recurrence and asymptomatic nature, and the significance of gynecologist intervention, especially oncologist gynecologist, on management of this patient.

\section{CASE REPORT}

We reported a case of a 37 year old female with lump on the left side of her vaginal lip for 2 weeks before admission. She admitted the lump on the left side of her vaginal lip was suddenly getting bigger. The lump was soft to touch and was not painful. She denied whether having fever, abnormal vaginal discharge, or bleeding from her genitalia. She also denied having difficulties in passing motion and urinating. Pelvic examination revealed a $5 \times 3$ $\mathrm{cm}$ lump with soft consistency on left vulva. Cervical and vaginal examination turned out to be normal.

Previously, the patient admitted she had a lump on the left side of her vaginal lip 3 years before admission. In the beginning, she found a lump that looked like a boil. She applied some Chinese medicine on top of the lump every day, and the lump burst and released pus on the third day, then the pus resolved. One year before admission, she found the same lump on the left side of her vaginal lip. She applied the same Chinese medicine on top of the lump and it burst and released pus from the lump then the lump resolved again. Few months later, she found same the lump again on the same spot. She applied the same Chinese medicine, but this time it did not work. She consequently chose alternative medicine and took herbal medication for 2 weeks, but she stopped taking those medications because the lump was getting bigger overnight. The lump was very painful and appeared very swollen. She described the appearance that the size was as big as a duck egg. The patient was then hospitalized in Pontianak for 2 weeks and underwent FNAB and CT-scan but with no reassuring result.

Her CT-scan showed circumscribed hypodense mass on left labia majora with $8.5 \times 2.7 \mathrm{~cm}$ of size with post contrast wall enhancement (as seen in Figure1), while FNAB examination showed hypocellular smear with myxoid matrix and bleeding. Then patient was transferred to Siloam MRCCC Jakarta and hospitalized for 1 month to undergo a surgical procedure by a general surgeon. The surgeon failed to totally excise the mass because of massive bleeding due to cut on a number of blood vessels on the surgical site.

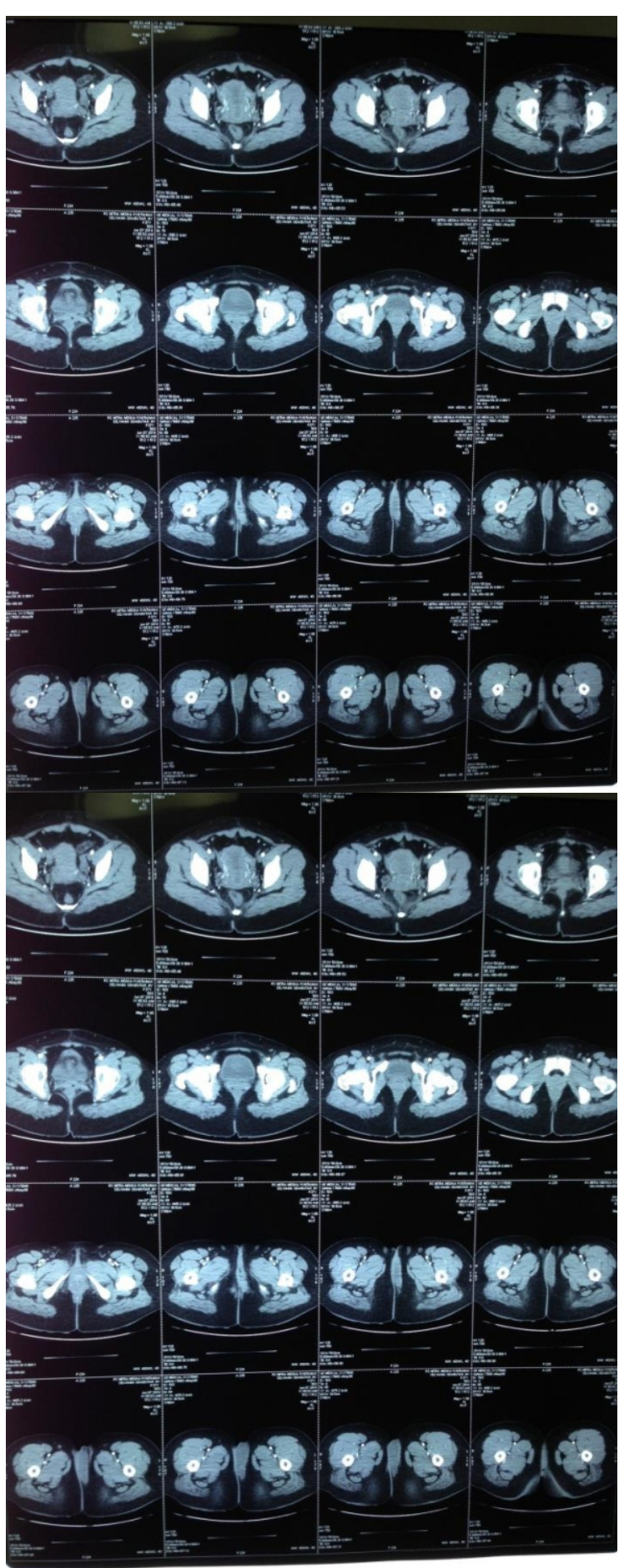

Figure 1. Abdomen-Pelvic CT Scan with contrast

Note: done in 2014 in Pontianak, with expertise of a soft tissue tumor in left labia majora, without abnormalities found in bladder, uterus, or rectum.

The patient required eight bags of blood transfusion, and admitted to intensive care unit. A severe infection was developed on her genital 3 days after admission. The patient said that the operated area was foul-smelling, bleeding, and pus was found around the suture. The patient also developed high fever thus she received intravenous antibiotics until her general condition improved. The patient was consulted to oncologist gynecologist in Siloam MRCCC and was planned for a vulvectomy and tumor removal with wide excision. The 
surgery went well and successfully removed the mass with $2 \mathrm{~cm}$ tumor margin, as shown in Figure 2 below.

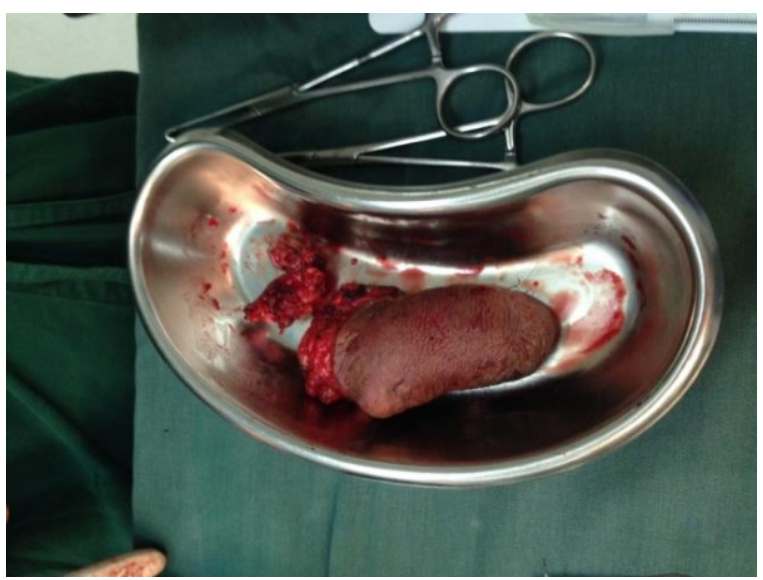

Figure 2. Aggressive angiomyxoma mass after being surgically removed

Note: Histopathological analysis specimen from labia majora sinistra: Proliferation of blood vessels are found, among collagen tissue and myxoid tissue. Among the myxoid tissue, stellate or spindle cells can be found. No nuclei mitotic or atypia are found. Conclusion: Aggressive Angiomyxoma, malignancy is not found.

\section{DISCUSSION}

Aggressive angiomyxoma is a rare mesenchymal tumor that most commonly arises in the vulvovaginal region, perineum, and pelvis of women (1). Aggressive angiomyxoma (AA) is most commonly found in women, but less commonly found in men (2). The age distribution of aggressive angiomyxoma is wide, commonly in reproductive age with the peak incidence from 31 to 35 years old (3). Our rare case also happen in her reproductive age, which was first found at 34 years of age.

The term aggressive was introduced to emphasize the locally aggressive behavior and the high potential for local recurrence (36-72\%) (4). It is defined as benign but has infiltrative potential into skeletal muscle and fat. The disease is therefore considered locally aggressive although it does not infiltrate surrounding viscus. The etiology is unknown. Aggressive angiomyxoma (AA) is most often found in or in proximity to the lower pelvis, more specifically perineum, vulva, vagina, or inguinal regions. The majority of patients present with a slowgrowing mass, often more than $10 \mathrm{~cm}$ in the largest diameter, which is asymptomatic and this is frequently the only symptom that occur, just like what we found in this case. Observed accompanying signs and symptoms are pain around the affected area, feeling of pressure, or dyspareunia. Our patient denied any pain at first. It presented as a painless, poorly circumscribed gelatinous vulvar mass and clinically simulates a bartholin gland cyst or an inguinal hernia.

The tumor cells are characteristically positive for estrogen and progesterone receptors, suggesting a hormonal role in the development of the tumor (1). Chromosomal translocation of the 12q13-15 band involving the HMGA2 gene has been described. Aggressive angiomyxoma (AA) must be diagnosed considering the age, clinical evolution, location, imaging assessment and anatomopathological and immunohistochemical evidence (5). However, due to the rarity of cases and lack of typical characteristics, the preoperative diagnosis is very difficult, hindering the therapeutic planning. Thus, most cases are confirmed histopathologically after the primary surgical resection (6).

Imaging studies are of great importance for the diagnosis of AA. The USG can reveal a polypoid, hypoechoic mass of soft tissue, which may appear as a cyst. At the CT, the characteristics vary and may include a homogeneous welldefined and hypodense mass relative in relation to the muscle, a hypoattenuating solid mass with an internal spiral pattern after intravenous contrast agent or a predominantly cystic mass with solid components (7). On T2-weighted MR imaging, the tumor has high signal intensity (Figure 3).

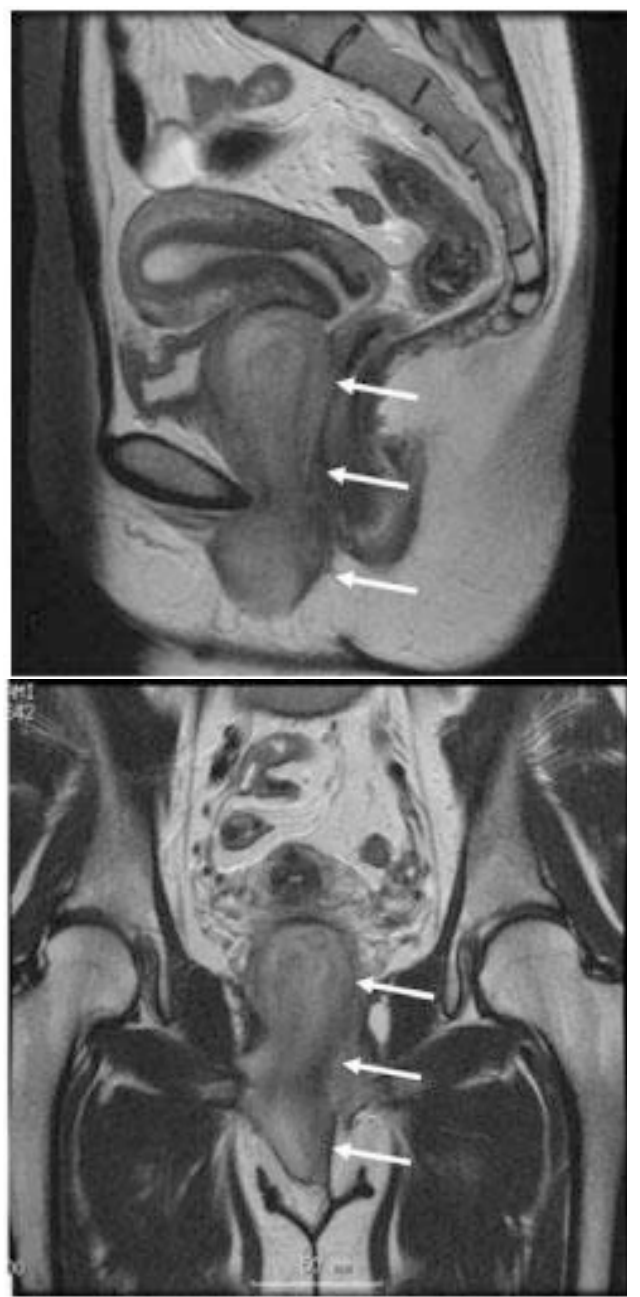

Figure 3. MRI Imaging of AA, showing internal spiral pattern (8)

Unfortunately, our patient did not undergo the MRI procedure with contrast, which may lead to misdiagnosis this rare angiomyxoma.

On gross examination, the tumors are characteristically soft, bulky masses with a smooth external surface. The histopathological examination shows myxoid stroma, hypocellularity, small spindled and stellate mesenchymal cells with undefined cytoplasm. So, some may underestimate it as a common soft tissue tumor or did not notice it. Pleomorphism and mitoses are not present and there is no evidence of coagulation necrosis in the tumor 
Table 1. Differential diagnosis of aggressive angiomyxoma (AA)(1)

\begin{tabular}{|c|c|c|c|c|c|}
\hline & Macroscopy & Stromal Mucin & Vessels & Other & Recurrence \\
\hline$A A$ & $5-60 \mathrm{~cm}$ & $\begin{array}{c}\text { Present, } \\
\text { between } \\
\text { collagen fibers }\end{array}$ & Variable calibers & $\begin{array}{l}\text { Genital, pereneal, pelvic } \\
\text { regions }\end{array}$ & Locally \\
\hline Superficial Angiomyxoma & $\begin{array}{l}\text { Small size, } \\
\text { multinodular, poorly, } \\
\text { circumscribed }\end{array}$ & Abundant & $\begin{array}{l}\text { Lack the large caliber } \\
\text { vessels }\end{array}$ & $\begin{array}{l}\text { Lobular architecture, mixed } \\
\text { inflammatory infiltrate, } \\
\text { squamous or basaloid cells }\end{array}$ & Locally \\
\hline Angiomyxomafibroblastoma & $\begin{array}{l}\text { Small size well } \\
\text { marginated, non } \\
\text { infiltrative }\end{array}$ & Minimal & $\begin{array}{l}\text { Abundant } \\
\text { vasculature lack the } \\
\text { large caliber vessels }\end{array}$ & $\begin{array}{l}\text { Highly cellular, vascular, rare } \\
\text { extravasation of red blood cells }\end{array}$ & None \\
\hline Myxofibrosarcoma & & Abundant & $\begin{array}{l}\text { Culvilinear branching } \\
\text { capillaries }\end{array}$ & Multinucleated atypical cells & High \\
\hline Myxoid liposarcoma & & Abundant & $\begin{array}{l}\text { Plexiform, thin- } \\
\text { walled }\end{array}$ & S100 protein (+) & High \\
\hline Myxoid neurofibroma & & Abundant & & More uniform cellular & None \\
\hline Cellular angiofibroma & Small size, $<3 \mathrm{~cm}$ & Minimal & $\begin{array}{l}\text { Hyalinized blood } \\
\text { vessels }\end{array}$ & $\begin{array}{l}\text { Mature adipocytes, collagen } \\
\text { bundles }\end{array}$ & None \\
\hline
\end{tabular}

cells. Characteristically, there is a prominent vascular component with vessels of various calibers. Infiltration into fat, muscle, and nerves is seen $(9,10)$. Immunohistochemically, most AAs are positive for desmin, smooth muscle actin, muscle-specific actin, vimentin, oestrogen receptor, and progesterone receptor (4).

The differential diagnosis of AA is based on other forms of soft tissue tumors (myxoma, myxoid lipoma, neurofibroma) and malignant tumors with metastatic potential (myxoid liposarcoma, myxofibrosarcoma, embryonal rhabdomyosarcoma) (7). Additionally, it can occasionally mimic Bartholin's cyst, labial cyst, Gartner's duct cyst and perineal herniation. The distinction of these tumors can be seen on Table 1.

Because of its high rate of local recurrence, the first line treatment for $A A$ is complete surgical resection with tumor free margin (1). Incomplete lesion resection occurs in $45-66 \%$ of cases and is directly associated with the possibility of recurrence, often requiring re-excision (3). Angiographic embolization can be used to adjunct the surgical removal of the tumor mass since it can shrink the tumor and make it easier to identify the tumor from surrounding normal tissues (11). Due to the low mitotic potential of this neoplasm, chemotherapy and radiotherapy are ineffective treatment (12). Treatment with gonadotropin-releasing hormone agonists is an emerging therapy and also can be used in case of incomplete resection or recurrence (1). As what happened in our patient, due to the vascularization and the bigger size of the tumor itself, the excision procedure is sometimes troublesome, but it can be prevented by a holistic approach.

The patient in this report exhibited a characteristics of AA based on the literature. The mass this 37 year old patient

\section{REFERENCES}

1. Sutton BJ and Laudadio J. Aggressive Angiomyxoma. Archives of Pathology \& Laboratory Medicine. 2012; 136(2): 217-221.

2. Akbulut M, Demirkan NC, Colakolgu N, and Duzcan E. Aggressive Angiomyxoma of the Vulva: A Case Report and Review of the Literature. Aegen Pathology has on her vulva was soft and painless with no accompanying symptoms. These findings should raise initial suspicion to $A A$, however, other differential diagnosis such as lipoma and neurofibroma also have to be considered due to its painless nature. After its recurrence, the mass started to be painful. This is mostly because of intervention of traditional medicine this patient received and may become the source of infection this patient has later. These symptoms, however, bring the patient to hospital to undergo examinations, including FNAB and CT scan of her mass. The CT scan result shows typical AA mass characteristics, which are hypodense and attenuated wall following a contrast injection. CT scan holds an important role on the management of this disease, since this examination enables visualization of the extent of this tumor invasion towards adjacent organs, easing the removal procedure done later. The FNAB result is the incriminating finding, showing hypocellular smear with myxoid matrix and bleeding, the two essential components of AA, hypocellular myxoid matrix and blood vessel.

The first surgical intervention this patient received was done by a general surgeon and is complicated by severe hemorrhage due to abundance of blood vessel on surgical site. This should give an insight of the difficulties on excising this type of mass. A deep knowledge of anatomy of perineal region is required to safely excising this mass due to its abundance of blood vessel. This also shows the importance of referring a patient with suspicion of AA to a gynecologist, especially an oncologist gynecologist, to prevent a severe complication from the surgery. Due to its recurring nature, it is important to do a routine follow up on these patients to detect any recurrences rising, so early management can be done either by medical therapy or by surgical therapy.

Journal. 2006; 3: 1-4.

3. Gungor T, Zengeroglu S, Kaleli A, and Kuzey GM. Aggressive Angiomyxoma of the Vulva and Vagina. A Common Problem: Misdiagnosis. European Journal of Obstetrics, Gynecology, and Reproductive Biology. 2004; 112(1): 114-116.

4. Micci F and Brandal P. Soft Tissue Tumors: Aggressive 
Angiomyxoma. Atlas of Genetics and Cytogenetics in Oncology and Haematology. 2007; 11(4): 340-343.

5. Minagawa T, Matsushita K, Shimada R, et al. Aggressive Angiomyxoma Mimicking Inguinal Hernia in a Man. International Journal of Clinical Oncology. 2009; 14(4): 365-368.

6. Bastian PJ, Fisang C, Schmidt ME, Biermann K, Textor J, and Müller SC. Aggressive Angiomyxoma of the Prostate Mimcking Benign Prostatic Hyperplasia. European Journal of Medical Research. 2006; 11(4): 167-169.

7. de Alencar SSS, Corrêa RS, de Menezes ESC, do Nascimento AL, da Costa DAA, and Alencar MJC. Recurrent Aggressive Angiomyxoma. Journal of Coloproctology (Rio de Janeiro). 2013; 33(4): 228231.

8. Wakimoto $\mathrm{T}$, Yoshino $\mathrm{K}$, Hori $\mathrm{Y}$, et al. Vulvovaginal Aggressive Angiomyxoma Mimicking Lymphedema
Complicated with Behcet's Disease: A Case Report and Review of the Literature. International Cancer Conference Journal. 2013; 2(2): 76-81.

9. Haldar K, Martinek IE, and Kehoe S. Aggressive Angiomyxoma: A Case Series and Literature Review. European Journal of Surgical Oncology. 2010; 36(4): 335-339.

10. Kondo T. Aggressive Angiomyxoma in the Inguinal Region: A Case Report. Journal of Medical Case Reports. 2010; 4:396.

11. Magtibay PM, Salmon Z, Keeney GL, and Podratz KC. Aggressive Angiomyxoma of the Female Pelvis and Perineum: A Case Series. International Journal of Gynecological Cancer. 2006; 16(1): 396-401.

12. Lourenço C, Oliveira N, Ramos F, Ferreira I, and Oliveria M. Aggressive Angiomyxoma of the Vagina: A Case Report. Revista Brasileira de Ginecologia e Obstetrícia. 2013; 35(12): 575-582. 